\title{
PURCHASING BEHAVIOUR OF CZECH SINGLES AND ITS CONSEQUENCES ON MARKETING COMMUNICATION EFFECTIVENESS
}

\author{
[Nákupní chování českých singles a jeho dopady na efektivitu marketingové \\ komunikace]
}

\author{
Martin Klepek $^{1}$, Kateřina Matušínská ${ }^{2}$ \\ ${ }^{1}$ Slezská univerzita, Obchodnè podnikatelská fakulta,Univerzitní nám. 1934/3,733 40 Karviná \\ Email:klepek@opf.slu.cz \\ ${ }^{2}$ Slezská univerzita, Obchodně podnikatelská fakulta, Univerzitní nám. 1934/3,733 40 Karviná \\ Email:matusinska@opf.slu.cz.
}

\begin{abstract}
This paper deals with marketing communication and purchasing behaviour of the specific group of single living consumers. The segment is growing in number in almost every developed region in the world as well as in the Czech Republic. The presented research is focused on the singles who live voluntarily outside the marriage and have own income and therefore a significant level of independency in consumption. The research has a descriptive character and a quantitative approach has been used. For the purpose of data collecting 702 singles filled a self-administrated online questionnaire. The statistics used in the research included frequency, percentage, and chi-square test. The research analysis showed a high influence of competition and sales, print flyers and loyalty programs. Analysing purchasing behaviour of singles who like buying new products and those for whom saving time is crucial when buying admits different effect of certain marketing communication tools. The aim of this article is to describe the behaviour of Czech singles and its consequences on marketing communication effectiveness.
\end{abstract}

Keywords: consumer behaviour, market segmentation, marketing communication, marketing communication mix, singles.

JEL classification: M31

Doručeno redakci: 21.12.2015; Recenzováno: 18.1.2016; 10.2.2016; Schváleno k publikování: 26.5.2016

\section{Introduction}

Single person households and shared households are both increasingly common, with many young adults remaining single for extended periods of time and developing extended friendship networks in support of their single lifestyle (Heat and Cleaver, 2003, p. 2). Young people today are likely to remain less oriented towards a traditional family life as they age (McRae, 1999, p. 25). These trends are evident mainly in developed countries in Western Europe, North America, Eastern Europe and Australia. Single living strategy of people is correlated with economic development of the country they live in. The last population census in 2011 in the Czech Republic showed the existence of 121420 persons living solo (Habartová, 2014). One can hardly believe that these dramatic changes will not affect consumer needs and behaviour. Hodgson (2007) stated in his report that the rise in single person households worldwide is creating great business opportunities for a range of sectors, including providers of online communications, manufacturers of domestic electrical appliances and consumer electronics, the construction industry, and the entertainment industry. Surprisingly, relatively few business researchers have paid serious attention to young people's changing attitudes towards household forming, despite their implications for new knowledge about specific needs which this group has. The aim of this article is to 
describe the behaviour of Czech singles and its consequences on marketing communication effectiveness.

\section{The nature and importance of market segmentation}

Marketing is a very dynamic discipline that constantly reacts to impulses of social-economic shifts and to needs of various entrepreneurial subjects. Companies can be successful if they actively apply marketing approach to the market. A clearly stated marketing philosophy, thorough knowledge of the market, organization subject to a marketing strategy and sufficient timing advance in decision making are absolutely necessary for a company to operate in the market environment. (Heczková and Stoklasa, 2011, p. 80) Nowadays companies cannot connect with all customers in large, broad, or diverse markets. But they can divide such markets into groups of consumers or segments with distinct needs and wants. A company then needs to identify which market segments it can serve effectively. This decision requires a keen understanding of consumer behaviour and careful strategic thinking. Identifying and satisfying the right market segments is often the key to marketing success. (Kotler and Keller, 2012, p. 235) To compete more effectively, many companies are now embracing target marketing. Instead of scattering their marketing efforts, they are focusing on those consumers they have the greatest chance of satisfying. Effective target marketing requires a wellconducted process of segmentation.

Segmentation is the process of splitting customers, or potential customers, in a market into different groups, or segments, within which customers share a similar level of interest in the same, or comparable, set of needs satisfied by a distinct marketing proposition (McDonald and Dunbar, 2012, p.14). In order to segment a market, it is important to understand who customers are, why they behave in particular ways and how they may be grouped together. Targeting decisions can then be made based on the range of identified segments. (Waite and Ennew, 2007) According to Levens (2012, p. 131) segmentation is the division of consumer markets into meaningful and distinct customer groups. Segmentation is a creative process and can be conducted using a range of different variables, each bringing a particular perspective to the dynamics of the market. Segmentation variables are the criteria that are used for dividing a market into segments. According to Drummond and Ensor (2005, p. 75 - 76) segmentation criteria can be divided into three main categories: profile, behavioural and psychographic variables. Marketers can use any variable at a starting point (first order variables), and then add further variables (second order variables) to give the grouping a clearer definition. Thus a segment of consumers seeking physical fitness may initially be determined using benefit segmentation. Profile variables may then be added such as age, gender, geo-demographics etc., in order to more clearly identify the consumer so that the company can develop specific media communication and distribution plans.

The future of marketing orientation of companies is to be found in the segments that are today regarded as marginal. Specific target groups are becoming increasingly a more interesting consumer segment, which is confirmed by the results of various realized foreign and domestic marketing studies. However, marketers still do not pay enough attention to this fact. Specific segments can be considered as future customers, their demand for goods and services will grow substantially due to their increasing solvency and adaptability to new trends. Consumer units such as singles can be considered as a current and strategic important segment. Donthu and Gilliand (2002) defined the singles' profile by the integration of marketing variables describing their consumption orientations. Singles are considered as a growing potential market but they still represent a misidentified target for marketing professionals. 
Singles are said to be people who have not married or their marriage was canceled, single people around 30 years old, but often all individuals who do not live in pairs, also widowed seniors or lonely middle-aged people. In a qualitative study of single people conducted in 2003 one particular finding stood out: a significant number of the interviewees (economically independent and without a partner) revealed their involvement in various other forms of regular or even long-term relationships. The existence of relationships that are not long-term or reproduction-oriented is not a result of any deliberate strategy but is rather a consequence of the complex changes in mentality and behaviour that occurred in the 1990s. These shifts, for example, relating to professional commitment and career satisfaction, tend to be understood as the explicit result of labour-market pressures on individual actors, but research has shown that, even at the level of individual actors, alternative approaches to partner relationships and reproduction are much more the result of people adopting and internalising post-1989 cultural templates. (Vysekalová et al., 2011, p. 262; Tomášek, 2006, p. 81)

Whether singlehood is really a manifestation of the individualization process partly depends upon whether singles actually favour an uncommitted life-style. Individualization may be conceived in two ways: a) as an increased freedom of choice in how to shape one's life, or b) as implying more individualistic attitudes that favour less commitment toward others. Hence, if singlehood would indeed be an expression of individualization, singles would have a positive view on singlehood according to both views. Contrary to this popular image, however, the group of singles who think singlehood is an attractive option might be relatively small and selective. Many studies have for example shown that singles generally do worse in terms of well-being and health than their married or cohabiting counterparts. (Poortman and Liefbroer, 2010, p. 938-939)

The segment of singles is not clearly defined in the Czech Republic or abroad. Only few marketing studies examined singles' consumption, because of the difficulty to obtain information. The content of the singles' category changes over time. Vysekalová (2011, p. 263) states, that the most commonly used criteria for the purpose of typology were developed by Staples and Stein. The Staple's criterion is the degree of the relationship openness: free floating unattached, open-coupled relationship, close-couple relationship, singles in one household and accommodationalist. The typology according to Stein takes into account voluntary and permanent of the state singles: voluntary temporary singles, stable voluntary, involuntary temporary, involuntary stable singles.

\section{Selected external marketing stimuli of purchasing behaviour}

The first step in formulating a marketing communication strategy is to identify, analyse and ultimately understand the target market and it buying behaviour. Buying behaviour is often more complex than it appears. Individuals are generally not very predictable, but, in the aggregate, groups of customers can be more predictable. There are three key groups of questions that have to be answered before any marketing communication can be carried out: Who is the buyer? Why do they buy (or not buy) a particular brand or product? How, when and where do they buy? The second question is the most difficult to answer. It requires qualitative rather than quantitative data. Products and services are bought for a range of different reasons or benefits, some conscious, others unconscious, some rational, others emotional. The split between emotional and rational reasons is called the "emotional-rational dichotomy". Many buyers buy for a mixture of reasons. (Smith and Zook, 2012, p. 90-93)

There are many different models that attempt to model the buyer's behaviour. The basic model highlights some of the stages through which a potential buyer passes. Marketers should endeavour to understand consumers' decision-making, the influence on this process, and in 
what way they can manipulate their marketing programmes to reflect these consumer needs and expectations. The standard consumer buying behaviour decision-making process involves a) recognition by a consumer that there is a problem for which the purchase of a product or service is the likely solution, b) the seeking of information to assist in selecting viable product or service options, c) the evolution of the evoked set of likely options, d) the final selection and purchase of one product or service, e) the on-going post-purchase subjective assessment of whether the specific item purchased was the "right" one. This final stage will impact on the process next time around. (Dibb and Simkin, 2007, p. 30)

The consumer decision-making process does not occur in vacuum. On the contrary, underlying cultural, social, individual and psychological factors strongly influence the decision process. Cultural factors, which include culture and values, subculture, and social class, exert the broadest influence over consumer decision making. Social factors sum up the social interactions between a consumer and influential groups of people, such as reference groups, opinion leaders, and family members. Individual factors, which include gender, age, family life-cycle stage, personality, self-concept, and lifestyle, are unique to each individual and play a major role in the type of products and services consumers want. Psychological factors determine how consumers perceive and interact with their environments and influence the ultimate decisions consumers make. They include perception, motivation, learning beliefs, and attitudes. (Lamb, Hair and McDaniel, 2009, p. 149)

Smith and Taylor (2004, p. 101) present three types of a purchasing model, "a black-box", "a personal-variable" and "a complex". Black box models consider external variables that act as stimuli (such as price, shops, merchandise, advertisements, promotions and the social environment including families and friends) and responses such as sales. Personal-variable models focus on some of the internal psychological variables such as attitudes and beliefs. The complex models attempt to include both internal and external variables in one grand model. The nature of consumer behaviour, focusing on when, why, how, and where people do or do not buy products, is illustrated in Table 1 below. The black box model shows how stimuli, consumer characteristics, and decision processes interact in eliciting consumer responses.

Table 1: Black Box Model

\begin{tabular}{|c|c|c|c|c|}
\hline \multicolumn{2}{|c|}{ ENVIROMENTAL FACTORS } & \multicolumn{2}{|c|}{ BUYER'S BLACK BOX } & \multirow[t]{2}{*}{$\begin{array}{c}\text { BUYER'S } \\
\text { RESPONSES }\end{array}$} \\
\hline Marketing Stimuli & $\begin{array}{c}\text { Environmental } \\
\text { Stimuli }\end{array}$ & $\begin{array}{c}\text { Buyer } \\
\text { Characteristics }\end{array}$ & $\begin{array}{l}\text { Decision } \\
\text { Processes }\end{array}$ & \\
\hline $\begin{array}{l}\text { Product } \\
\text { Price } \\
\text { Place } \\
\text { Promotion }\end{array}$ & $\begin{array}{l}\text { Economic } \\
\text { Technical } \\
\text { Political } \\
\text { Cultural }\end{array}$ & $\begin{array}{l}\text { Attitudes } \\
\text { Motivation } \\
\text { Perceptions } \\
\text { Personality } \\
\text { Lifestyle }\end{array}$ & $\begin{array}{c}\text { Problem } \\
\text { recognition } \\
\text { Information } \\
\text { search } \\
\text { Alternative } \\
\text { evaluation } \\
\text { Purchase decision } \\
\text { Post-purchase } \\
\text { behaviour }\end{array}$ & $\begin{array}{l}\text { Product choice } \\
\text { Brand choice } \\
\text { Dealer choice } \\
\text { Purchase timing } \\
\text { Purchase amount }\end{array}$ \\
\hline
\end{tabular}

Source: modified according to Sandhusen (2008, p. 218) 
Marketing communications is defined as controlled informing and persuading the target groups when companies and other institutions fulfil their marketing goals. Marketing communication must be based on the overall marketing strategy. (Karlíček et al. 2013, p. 190) There are many other effective communication tools that may influence the purchasing decisions of consumers. According to Karlíček and Král (2011) the concept of marketing communication mix is based on seven main elements: advertising, sales promotion, personal selling, public relations, direct marketing, sponsorship and online marketing communication.

In the area of sales promotion, the suitably chosen merchandising at the point of sale can be said as the basic marketing stimuli, which can very effectively and impulsively influence the purchasing behaviour of consumers. Physical evidence is the environment in which the service is delivered, and any tangible goods that facilitate the performance and communication of the service. Customers look for clues to the likely quality of a service by inspecting the tangible evidence. (Jobber, 2010, p. 846)

Merchandising is a specific area of sales promotion, the purpose of which is to achieve maximum persuasion at the point of sale. It is a comprehensive care of goods and POP displays at the point of sale, including the care of the visual aspect of the store. (Jurášková, Horńák et al., 2012, p. 134) Smith and Zook (2012) argue that the aim of merchandising is to change the passive offer to the active offer. Merchandising does not apply just to the traditional retail outlets of supermarkets, garages and department stores, but also to DIY stores, brown-goods retailers (stereos and TVs), corner shops, office-equipment showrooms and cash-and-carry wholesalers.

The type of shop environment must be "friendly and inviting". The seller, of course, pays attention to sales maximizing. This can be achieved by a proper distribution of goods at the point of sale to navigate customers and stimulate them to buy in a complex way. In this context, cross-merchandising (trade compatibility) as the specific sales technique can be mentioned. It reminds the customer of related end-use products, which are carefully positioned beside each other.

Marketing communication is usually designed to appeal primarily to consumers' senses of vision and hearing. Yet, consumers' decision making processes are also influenced by other sensory information. Marketers understand that auditory and visual influences alone can be insufficient to persuade consumers and that increased persuasiveness can be achieved by targeting the senses of touch, taste and smell. (Rimkute, Moraes and Ferreira, 2015)

The application of sensory (experiential) marketing is typical exactly at the point of sale, this is called as sensory merchandising, which represents a new form of in-store marketing. It uses factors which create an atmosphere in the store (music, smell, colour, taste and tactile elements) and give the consumers a positive response for the purchase of certain kinds of goods. Psychological studies have shown that the environment can affect mood, emotional reactions, thoughts and physical reactions of individuals. Sensory merchandising examines the way how the customer responds to the physical retail environment. While the visual and auditory cues are widely used in this respect, the importance of olfactory, gustatory and tactile perception is increasingly explored and understood.

POP (point of purchase) displays influence on consumers at the place of purchase where it is not necessary to activate their memory functions. In many consumer markets the consumer's final decision to buy is often made inside, and not outside, the store. It is said that about $75 \%$ 
of all purchase decisions are realized at the point of sale. The percentage of impulse purchases are about $60-75 \%$, but it depends on the product category. An important source of further POP displays functionality increasing is their cooperation with other communication tools used the communication campaign. (Boček et al., 2009, p. 16)

People generally vary considerably in the case of willingness to try new products. Rogers $(1995$, p. 263 - 265) has hypothesized that the noncumulative adoption pattern is a normal distribution. Roger has suggested that there are five categories of adopters of a new-product innovation based on when they adopt an innovation: innovators: venturesome (2.5\%), early adopters: respect (13.5\%), early majority: deliberate (34\%), late majority: skeptical (34\%), and laggards: traditional (16\%).

The early adopters are especially young, restless, the better-educated and they provide significant insights into overall consumer acceptance and are the most likely candidates to determine a new product's success. Early adopters tend to communicate their likes and dislike with others and they adopt new products quickly. Early adopters are an important marketing target for several reasons. First, they are a larger group than innovators. Second, they are trend setters. Third, early adopters spread the WoM to the next group, the early majority. Finally, early adopters provide the initial revenues for a new technology. (Siomkos and Mourdoukoutas, 2009).

\section{Sample and methods}

The subject of this study are Czech singles living voluntarily alone. The data was obtained in 2014 and 2015 through two independent online panels to ensure respondent heterogenity. There were two sets of panellists - one motivated by financial incentives, the other took part in research voluntarily. All participants were contacted through email and provided data through a self-administrated online questionnaire.

We used control questions to ensure that respondents match our definition of singles by asking them about their marital status, cohabitation and independent income. Answers indicating improper respondents were not used for the further statistical analysis. Typically these were individuals living with parents, married or students without own income.

The sample consist of 702 respondents and women prevail with $55.4 \%$ over men $(44.6 \%)$. Most of the surveyed singles has never been married (85.8\%) while the rest is divorced $(12.5$ $\%)$ or widowed $(1.7 \%)$. Nearly half of them have a certificate from a high school with GCSE and the largest age group is between 26 and 35 years of age. Further details are provided in Table 2. 
Table 2: Demographic characteristics of the respondents

\begin{tabular}{|l|l|l|}
\hline \multicolumn{1}{|c|}{ Respondent's characteristics } & \multicolumn{1}{c|}{$\begin{array}{c}\text { Number of } \\
\text { respondents }\end{array}$} & \% of respondents \\
\hline Male Marital status & \multicolumn{1}{c|}{ (313 } & 44,6 \\
\hline Female Education & 389 & 55,4 \\
\hline Never married & 602 & \\
\hline Divorced Age group & 88 & 85.8 \\
\hline Widowed & 12 & 12.5 \\
\hline & & 1.7 \\
\hline Elementary school & 44 & \\
\hline High school & 134 & 6.3 \\
\hline High school with GCSE & 299 & 19.1 \\
\hline University & 225 & 42.6 \\
\hline & & 32.1 \\
\hline$<25$ & 181 & \\
\hline $26-35$ & 234 & 25.8 \\
\hline $36-45$ & 138 & 33.3 \\
\hline $46-55$ & 89 & 19.7 \\
\hline $56-65$ & 49 & 12.7 \\
\hline$>66$ & 11 & 7 \\
\hline Source: & & 1.6 \\
\hline
\end{tabular}

Source: own research

We questioned these consumers about their past behaviour within the topic of marketing communication tools and purchasing behaviour.

The Chi-Square $(\chi 2)$ test of independence for a contingency table was used for evaluation and all relationships were tested on the level of significance of $\alpha=0.01$. Pearson's chi-square test is given by (1):

$$
\chi^{2}=\sum \frac{\left(f_{o}-f_{e}\right)^{2}}{f_{e}}
$$

Where:

$\mathrm{f}_{\mathrm{o}}=$ the observed frequencies for each position in the matrix;

$\mathrm{f}_{\mathrm{e}}=$ an expected frequencies for each position in the matrix.

For measure of association Phi-coefficient was used (̌̌ezanková, 1997) given by (2):

$$
\Phi=\sqrt{\frac{\chi^{2}}{n}}
$$

$\mathrm{n}=$ number of cases.

We asked five dichotomous yes or no questions about purchasing habits (PH1-5) and seven questions about admitted influence of a particular marketing communication tool (MCT1-7) on decision making process. We then asked questions about basic segmentation information. Thanks to the descriptive nature of the research we set basic research question as follows: How admitted influence of specific marketing communication tool relate to purchasing habits of singles? In pursuit to answer this question we statistically compared the answers using Pearson's chi-square test. Every single pair MCT-PH resulted in $35 \chi^{2}$ values. 


\section{Results}

Before we compare the differences between purchasing behaviours and assessing the impact of marketing tools, it is necessary to present the results of descriptive statistics. Figure 1 shows frequencies of singles falling into specific purchasing behaviour groups. Dominant behaviours are related to time saving buying (PH5) and also appearance of place (PH1) where consumers shop.

In theory, innovators and early adopters accounts for $16 \%$ of consumers in total (Rogers, 1995). Empirical results show a greater willingness to try new goods and services compared to general public since $21 \%$ of singles like to buy and try new products (PH2). Younger singles have higher willingness to try the new products. On the other hand, around one fifth consists of singles who strictly buy same products and trust previous experience (PH3).

Figure 1: Purchasing habits of the respondents

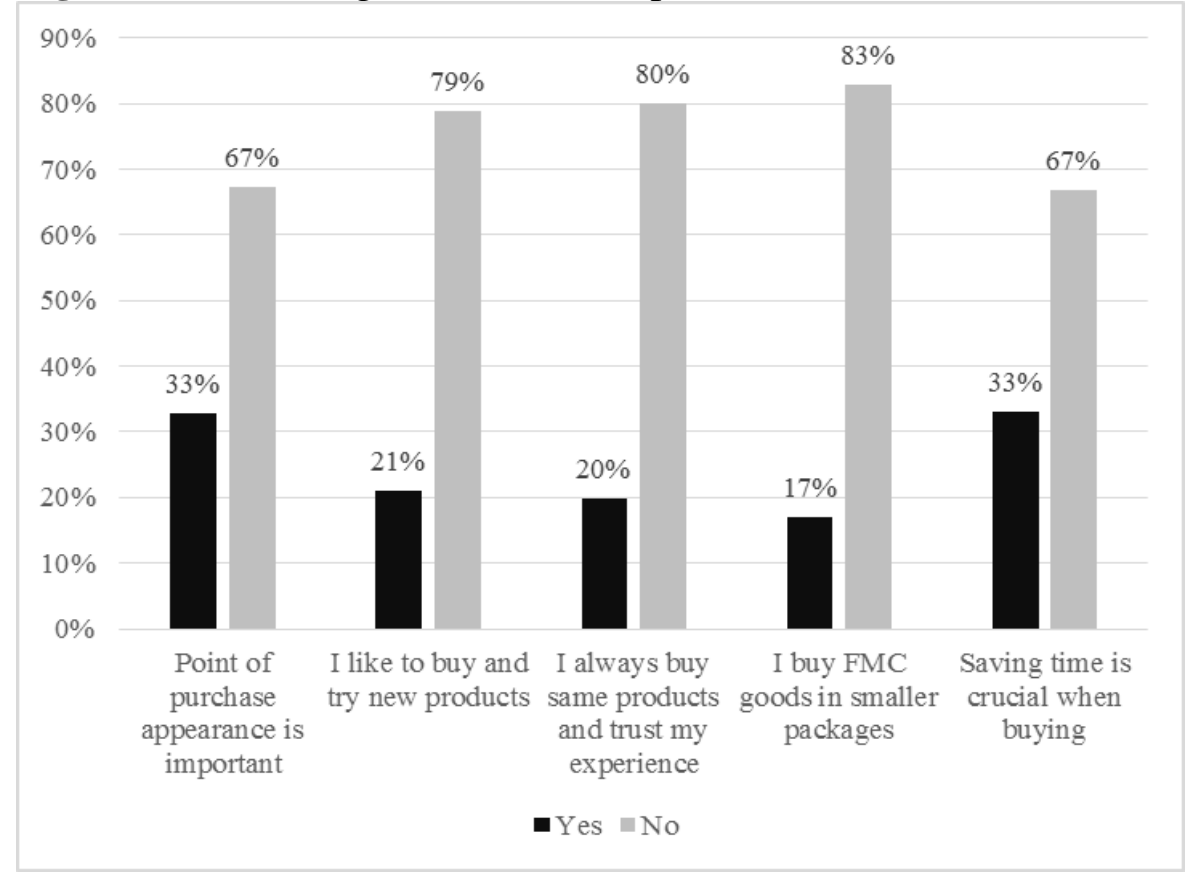

Source: own research

Many would say that singles are demanding tailored products for their consumption. Smaller washing machines, fridges, dishwashers etc. are on the market. But when it comes to fast moving consumer goods, surprisingly only $17 \%$ of respondents buy small packages (PH 4). To interpret this finding we have to consider two things. Fristly, Czech market is not that advanced and producers are not offering packages for single persons on regular basis. They dominantly consider family as a target group and a main unit of interest. Consumers then have no option to form the habit of buying small packages. Secondly, we have to look at the Figure 2 and take a broader perspective. Most influential communication tools are competitions and sales. Second are print flyers (33\%) which mostly provide information about sales promotion, special offers and discounted products as well as loyalty programs $(30 \%)$ which offer bonuses for loyal customers and do not tailor the product at the first place. That is to say, singles prefer value over convenience and majority of them probably buy standard packages to save money.

Points of purchase materials (13\%) are less influential as well as mainstream media such as $T V$, radio and print $(13 \%)$. At the bottom there are newsletter $(8 \%)$ and Internet banners 
(7\%). Surprisingly these modern tools have low popularity even compared to traditional media formats.

Figure 2: Influence of marketing communication tools on the respondents

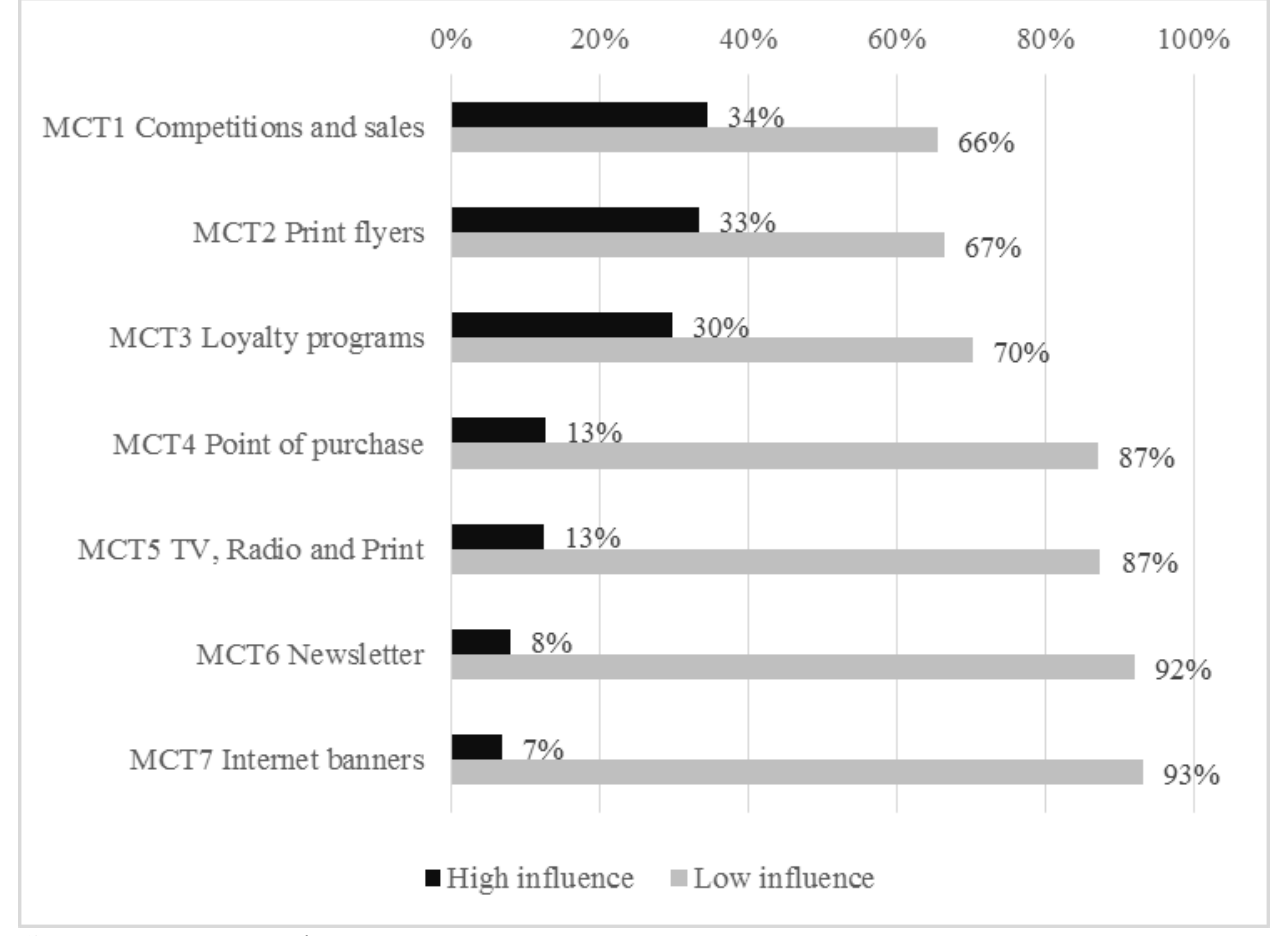

Source: own research

Table 3 shows comparison of buying behaviours and influence of MCT. In the first case, internal environment of a store (PH1) does not relate to any of MCT. The same applies to repetitive buying of same products (PH3) and smaller packages (PH4). Further, singles who like to buy new products (PH2) responds differently to MCT 1, 3, 4, 6, 7 and those for whom a saving time is crucial when buying (PH5) respond differently to MCT 1,2, 5. We found 8 statistically significant associations in total and these are analysed further.

Table 3: Chi-square values

\begin{tabular}{|l|l|l|l|l|l|l|}
\hline & \multicolumn{1}{|c|}{ Purchasing habit } & \multicolumn{1}{|c|}{ PH1 } & \multicolumn{1}{|c|}{ PH2 } & \multicolumn{1}{|c|}{ PH3 } & \multicolumn{1}{|c|}{ PH4 } & \multicolumn{1}{|c|}{ PH5 } \\
\hline $\begin{array}{c}\text { Point of } \\
\text { purchase } \\
\text { appearance } \\
\text { is } \\
\text { important }\end{array}$ & $\begin{array}{c}\text { I like to } \\
\text { buy and } \\
\text { try new } \\
\text { products }\end{array}$ & $\begin{array}{c}\text { I always } \\
\text { buy same } \\
\text { products } \\
\text { and trust } \\
\text { my } \\
\text { experience }\end{array}$ & $\begin{array}{c}\text { I buy } \\
\text { goods in } \\
\text { smaller } \\
\text { packages }\end{array}$ & $\begin{array}{c}\text { Saving } \\
\text { time is } \\
\text { crucial } \\
\text { when } \\
\text { buying }\end{array}$ \\
\hline MCT1 & Competitions and sales & 0.070 & $\mathbf{0 . 0 0 0 . . . *}$ & 0.213 & 0.477 & $\mathbf{0 . 0 0 2 *}$ \\
\hline MCT2 & Print flyers & 0.394 & 0.064 & 0.709 & 0.860 & $\mathbf{0 . 0 0 3}$ \\
\hline MCT3 & Loyalty programs & 0.043 & $\mathbf{0 . 0 0 3} *$ & 0.334 & 0.349 & 0.022 \\
\hline MCT4 & Point of purchase & 0.185 & $\mathbf{0 . 0 0 6} *$ & 0.405 & 0.475 & 0.133 \\
\hline MCT5 & TV, Radio and Print & 0.656 & 0.720 & 0.875 & 0.127 & $\mathbf{0 . 0 0 3 *}$ \\
\hline MCT6 & Newsletter & 0.846 & $\mathbf{0 . 0 0 0 . . . *}$ & 0.772 & 0.832 & 0.012 \\
\hline MCT7 & Internet banners & 0.685 & $\mathbf{0 . 0 0 4} *$ & 0.830 & 0.381 & 0.029 \\
\hline
\end{tabular}

$* \chi^{2}$ values over critical value (for $\chi^{2}$ at 0.01 is 6.63 for 1 degree of freedom)

** In all cases the expected counts were higher than 5.

Source: own research 
From a closer look at the Table 4, we can describe measured differences within the category of early adopters or innovators (PH2) comparing real and expected counts. This category of singles admits higher influence of competition and sales, loyalty programs, point of purchase, newsletter and Internet banners on their purchasing decisions. Apart from the statistical significance and expected/real count comparison we also provide results of Phi-coefficient $(\Phi)$ which gives us not only a measure of association but also attempts to compare it across the observed relationship. In this case the strongest association is within the competitions and sales $(\Phi=0,176)$ at the second place is newsletter $(\Phi=0,131)$ and the third are loyalty programs $(\Phi=0,114)$. In this case association goes in positive direction. High influence of MCT was observed in more cases than expected.

Table 4: I like to buy and try new products

\begin{tabular}{|l|l|l|l|l|l|c|}
\hline \multicolumn{2}{|c|}{$\begin{array}{c}\text { PH2: I like to buy and try } \\
\text { new products }\end{array}$} & \multicolumn{2}{c|}{ No } & \multicolumn{2}{c|}{ Yes } & $\Phi$ \\
\cline { 3 - 7 } & & Count & Expected Count & Count & Expected Count & Phi \\
\hline $\begin{array}{l}\text { MCT1 Competitions } \\
\text { and sales }\end{array}$ & High & 167 & 191 & 78 & 51 & 0.176 \\
\cline { 2 - 7 } & Low & 387 & 363 & 73 & 97 & \\
\hline \multirow{2}{*}{ MCT3 Loyalty programs } & High & 150 & 164.9 & 59 & 44.1 & 0.114 \\
\cline { 2 - 7 } & Low & 404 & 389.1 & 89 & 103.9 & \\
\hline \multirow{2}{*}{ MCT4 Point of purchase } & High & 61 & 71 & 29 & 19 & \multirow{2}{*}{0.105} \\
\cline { 2 - 6 } & Low & 493 & 483 & 119 & 129 & \\
\hline \multirow{2}{*}{ MCT6 Newsletter } & High & 34 & 44.2 & 22 & 11.8 & \\
\cline { 2 - 7 } & Low & 520 & 509.8 & 123 & 136.2 & \\
\hline \multirow{2}{*}{ MCT7 Internet banners } & High & 30 & 37.9 & 18 & 10.1 & \\
\cline { 2 - 6 } & Low & 524 & 516.1 & 130 & 137.9 & \\
\hline
\end{tabular}

Source: own research

Respondents who want to save time when buying (PH5) recognize all three MCTs to be less influential than expected. The relationship is therefore in opposite direction compared to those of the previous group ( $\mathrm{PH} 2)$. Table 5 also provides comparison of the strength of the association where competition and sales $(\Phi=0,115)$ are at the top followed by print flyers $(\Phi$ $=0,113)$ and $\mathrm{TV}$, radio and print $(\Phi=0,115)$.

Table 5: Saving time is crucial when buying

\begin{tabular}{|l|l|l|l|l|l|c|}
\hline \multicolumn{2}{|c|}{$\begin{array}{c}\text { PH5: Saving time is crucial } \\
\text { when buying }\end{array}$} & \multicolumn{2}{c|}{ No } & \multicolumn{2}{c|}{ Yes } & $\Phi$ \\
\cline { 3 - 7 } & & Count & Expected Count & Count & Expected Count & Phi \\
\hline \multirow{2}{*}{$\begin{array}{l}\text { MCT1 Competitions } \\
\text { and sales }\end{array}$} & High & 180 & 162 & 62 & 80 & 0.115 \\
\cline { 2 - 7 } & Low & 290 & 308 & 170 & 152 & \\
\hline \multirow{3}{*}{ MCT2 Print flyers } & High & 175 & 157.3 & 60 & 77.7 & 0.113 \\
\cline { 2 - 7 } & Low & 295 & 312.7 & 172 & 154.3 & \\
\hline \multirow{2}{*}{ MCT5 TV, Radio and Print } & High & 71 & 58.9 & 17 & 29.1 & 0.111 \\
\cline { 2 - 6 } & Low & 399 & 411.1 & 215 & 202.9 & \\
\hline
\end{tabular}

Source: own research

\section{Conclusion}

Singles are growing in number in almost every developed region in the world. This trend is evident also in Czech Republic. Despite this fact very little academic research aims to describe the segment and its specific needs and behaviours. This article, essentially 
descriptive, provides information about purchasing behaviours and admitted influence of marketing communication tools within the group. Research question has been answered by describing all relationships and its association strengths.

Singles tend to buy and try new products slightly more than theoretical concepts for new product adoption suggest. Nearly the same amount of singles buys based on their previous experience and follow certain habitual patterns. This behaviour vary across the sample depending on the age of the respondents. Young singles experiment more with products compared to older ones which rely on certainty. Saving time when buying is crucial for one third of them as well as the point of purchase appearance. The most surprising finding is that only $17 \%$ buy small packages which are commonly perceived as tailored for specific need of the solo living person. From these specific purchasing behaviour information one can consider singles as diverse segment homogenous in a lifestyle but heterogeneous in purchases.

As the group provides various subsets of consumers, data illustrating marketing communication influence can be compared within each group. Singles who like to buy and try new products are more influenced by five marketing communication tools from which competition and sales and newsletters are the most important. The second difference can be found in the group of singles for whom the saving time element is crucial when buying. Competition and sales are the most significant.

Overall the singles in the Czech Republic are mostly influenced in their buying decisions by competition and sales, print flyers and loyalty programs. All of these tools are connected with special offers and bargains. This finding shows singles in a slightly different light than traditional mainstream stereotypical perception of solo living persons, rich and career building, highly individual and fully enjoying their lifestyle.

The research results provide some practical implications. The marketers should always consider singles as diverse group with all its sub-segments. The traditional perception of the segment is different from the reality and singles have various purchasing habits. Moreover Czech singles are still strongly influenced by competition and sales and therefore ignoring the benefits of small products packages for their consumption. Communicating the usefulness of small packages for single living person should go hand by hand with emphasis on price comparability with large packages. Research also showed some product adoption patterns. When targeting young singles, marketers could use more of competition and sales, loyalty programs, point of purchase promotion or newsletters.

\section{Acknowledgement:}

This paper was supported by the Student grant competition project SGS/23/2014: "Consumer behaviour of the specific segment in the Czech Republic." The data were partly collected through Instant Research Ipsos.

\section{Literature}

[1] BOČEK, M., D. JESENSKÝ and D. KROFIÁNOVÁ, 2009. POP In-store komunikace $v$ praxi. Trendy a nástroje marketingu v mistě prodeje. Praha: Grada Publishing. ISBN 978-80-247-2840-7.

[2] DIBB, S. and L. SIMKIN, 2004. Marketing Briefs $-a$ Revision and Study Guide. $2^{\text {nd }}$ ed. Oxford: Elsevier. ISBN 978-0-7506-6200-0. 
[3] DRUMMOND, G. and J. ENSOR, 2005. Introduction to Marketing Concepts. Oxford: Elsevier. ISBN 0-7506-59995-5.

[4] GILLILAND, D. I., and N. DONTHU, 2002. The single consumer. Journal of Advertising Research, 42(6), 77-84. ISSN 0021-8499.

[5] HABARTOVÁ, P., 2014. Singles tvoří již pětinu domácností jednotlivců. Statistika a My [online]. 4(5) [vid. 5. prosince 2015]. Dostupné z: www.statistikaamy.cz/wpcontent/uploads/2014/05/18041405.pdf

[6] HEAT, S. and E. CLEAVER, 2003. Young, Free and Single?: Twenty-somethings and Household Change. New York: Palgrave Macmillan. ISBN 978-0230502871.

[7] HECZKOVÁ, M. and M. STOKLASA, 2011. Customer Relationship management Theory and Principles. Acta academica karviniensia, 14(4), 80-91. ISSN 1212-415X.

[8] HODGSON, A., 2007. One-Person Households: Opportunities for Consumer Good Companies [online]. Euromonitor International. [vid. 9. prosince 2015]. Dostupné z: blog.euromonitor.com/2007/09/one-person-households-opportunities-for-consumergoods-companies.html

[9] JOBBER, D., 2010. Principles and Practice of Marketing. $6^{\text {th }}$ ed. Berkshire: McGrawHill Education. ISBN 978-007712330-7.

[10] JURÁŠKOVÁ, O. and P. HORŇÁK, 2012. Velký slovník marketingových komunikací. Praha: Grada Publishing. ISBN 978-80-247-4354-7.

[11] KARLÍČEK, M. and P. KRÁL, 2011. Marketingová komunikace - Jak komunikovat na našem trhu. Praha: Grada Publishing. ISBN 978-80-247-3541-2.

[12] KARLÍČCK, M. et al., 2013. Základy marketingu. Praha: Grada Publishing. ISBN 97880-247-4208-3.

[13] KOTLER, P. and K. L. KELLER, 2012. Marketing Management. $14^{\text {th }}$ ed. Harlow: Pearson Education Limited. ISBN 978-0-13-210292-6.

[14] LAMB, CH. W., J. F. HAIR and C. McDANIEL, 2009. The essentials of marketing. 6th ed. Mason: South-Western Cengage Learning. ISBN 978-0-324-69620-6.

[15] LEVENS, M., 2012. Marketing: Defined, Explained, Applied. $2^{\text {nd }}$ ed. New Jersey: Pearson education. ISBN 978-0-13-271989-6.

[16] McDONALD, M. and I. DUNBAR, 2012. Market Segmentation: How to Do It and How to Profit from It. $4^{\text {th }}$ ed. John Wiley \& Sons. ISBN 9781118432754.

[17] McRAE, S., 1999. Changing Britain: Families and Households in the 1990s. Oxford: Oxford University Press. ISBN 978-0198296379.

[18] POORTMAN, A-R. and A. C. LIEFBROER, 2010. Singles' relational attitudes in a time of individualization. Journal of Social Science Research, 39, 938-949. ISSN 0049-089X.

[19] RIMKUTE, J., C. MORAES and C. FERREIRA, 2015. The effects on scent on consumer behaviour. International Journal of Consumer Studies, 40(1), 24-34 ISSN 1470-6423.

[20] ROGERS, E. M., 1995. Diffusion of Innovations. $4^{\text {th }}$ ed. New York: The free press. ISBN 0-02-926671-8.

[21] ŘEZANKOVÁ, H., 1997. Analýza kategoriálních dat pomocí SPSS. Praha: VŠE Praha. ISBN 80-7079-728-2. 
[22] SANDHUSEN, R. L., 2008. Marketing. $3^{\text {rd }}$ ed. New York: Barron's Educational Series, Inc. ISBN 978-0-7641-3932-1.

[23] SIOMKOS, G. J. and P. MOURDOUKOUTAS, 2009. The seven principles of WOM and Buzz marketing: crossing the tipping point. Berlin: Springer-Verlag Berlin Heidelberg. ISBN 978-3-642-02108-4.

[24] SMITH, P. R. and J. TAYLOR, 2004. Marketing communications, an integrated approach. $4^{\text {th }}$ ed. London: Kogan Page. ISBN 0749442654.

[25] SMITH, P. R and Z. ZOOK, 2012. Marketing Communications: Integrating offline and online with social media. $5^{\text {th }}$ ed. Philadelphia: Kogan Page Limited. ISBN 978-0-74946193-5.

[26] TOMÁŠEK, M., 2006. Singles a jejich vztahy: kvalitativní pohled na nesezdané a nekohabitující jednotlivce v České republice. Czech Sociological Review, 42(1), 81-105. ISSN 0038-0288.

[27] VYSEKALOVÁ, J. et al., 2011. Chování zákaznika: Jak odkrýt tajemství černé skřiňky. Praha: Grada Publishing. ISBN 9788024735283.

[28] WAITE, N. and CH. T. ENNEW, 2007. Marketing of Financial Services. Oxford: Elsevier Ltd. ISBN 978-0-7506-6997-9. 